\title{
Pengintegrasian Nilai-nilai Imtaq dengan Media Grafis terhadap Hasil Belajar IPS Terpadu Siswa Kelas VIII SMPN 2 Jerowaru
}

\author{
Muhamad Zaril Gapari \\ STIT Palapa Nusantara Lombok NTB \\ zagap205@yahoo.co.id
}

\begin{abstract}
The purpose of this study was to determine the integration of imtaq values with graphic media in integrated social studies learning on student learning outcomes. This research was conducted at Jerowaru 2 Public High School in class VIII. The type of this research is experimental research, and in this study the independent variable is the integration of imtaq values with graphic media and the dependent variable is student learning outcomes on the subject of demand and supply (buying and selling). While the research sample is class VIII-A as an experiment (using integration of imtaq values with graphic media) and class VIII-B as a control class and the instrument used is an objective test consisting of 25 items. Based on the results of data analysis, obtained the average value of the group using the integration of imtaq values with 58.86 graphic media and the group using integration of imtaq values without the graphic media is 55.05 means that the use of integrating imtaq values with graphic media can improve learning outcomes students. While the results of bypothesis testing obtained t-count is greater than $t$-table, namely 1.925> 1.684. This means that the proposed bypothesis is accepted (Ho rejected and Ha accepted), namely the use of integrating imtaq values with graphic media more effectively to improve student learning outcomes when compared to those who do not use the integration of imtaq values without graphic media in class VIII Jerowaru Junior High School 2.
\end{abstract}

Keywords: Integration of Imtaq Values, Graphic Media, Learning Outcomes.

\begin{abstract}
Abstrak : Tujuan penelitian ini adalah untuk mengetahui pengintegrasian nilai-nilai imtaq dengan media grafis dalam belajar IPS Terpadu terhadap hasil belajar siswa. Penelitian ini dilaksanakan di SMPN 2 Jerowaru pada kelas VIII. Adapun jenis penelitian ini adalah penelitian eksperimen, dan dalam penelitian ini yang menjadi variabel bebas adalah pengintegrasian nilai-nilai imtaq dengan media grafis dan variabel terikatnya adalah hasil belajar siswa pada pokok bahasan permintaan dan penawaran (jual beli). Sementara sampel penelitiannya adalah siswa kelas VIII-A sebagai eksperimen (menggunakan pengintegrasian nilai-nilai imtaq dengan media grafis) dan kelas VIII-B sebagai kelas kontrol dan instrumen yang digunakan adalah tes obyektif yang terdiri dari 25 butir soal. Berdasarkan hasil analisis data, diperoleh nilai rata-rata kelompok yang menggunakan Pengintegrasian nilai-nilai imtaq dengan media grafis 58,86 dan kelompok yang menggunakan pengintegrasian nilainilai imtaq tanpa media grafis tersebut adalah 55,05 berarti bahwa penggunaan pengintegrasian nilai-nilai imtaq dengan media grafis dapat meningkatkan hasil belajar siswa. Sedangkan dari hasil uji hipotesis diperoleh t-hitung lebih besar dari t-tabel yaitu $1,925>1,684$. Hal ini berarti bahwa hipotesis yang diajukan diterima (Ho

Islamika : Jurnal Keislaman dan Ilmu Pendidikan

Volume 1, Nomor 2, Juli 2019; 1-17

https:// ejournal.stitpn.ac.id/index.php/islamika
\end{abstract}


ditolak dan Ha diterima) yaitu Penggunaan pengintegrasian nilai-nilai imtaq dengan media grafis lebih efektif untuk meningkatkan hasil belajar siswa bila dibandingkan dengan yang tidak menggunakan pengintegrasian nilai-nilai imtaq tanpa media grafis pada siswa kelas VIII SMPN 2 Jerowaru.

Kata Kunci: Pengintegrasian Nilai-nilai Imtaq, Media Grafis, Hasil Belajar.

\section{PENDAHULUAN}

Masalah pendidikan yang utama di Indonesia adalah sangat rendahnya mutu pendidikan pada setiap jenjang pendidikan, Setelah dilakukan penanggulangan dalam bidang pendidikan, semakin disadari masih banyak kekurangan-kekurangan yang mendasar, salah satu kekurangan tersebut adalah terletak pada inti kegiatan pendidikan itu sendiri yaitu pada proses belajar mengajar yang melibatkan anak didik dan yang mendidik.

Hasil studi tentang pembelajaran di instansi-instansi menunjukkan bahwa model pembelajaran khususnya IPS sangat teoritis, dan lebih banyak menggunakan metode ceramah atau latihan soal, dengan demikian siswa merasa sulit untuk memahami konsep-konsep IPS dan akhirnya menyebabkan rendahnya motivasi siswa untuk belajar.

Dalam upaya peningkatan kualitas sumber daya manusia yang dilaksanakan melalui jalur pendidikan merupakan tugas besar dan berjangka waktu panjang, sehingga harus melalui proses yang baik dan terarah, sesuai apa yang tercantum dalam Undang-Undang Sisdiknas No.20 Tahun 2003 Bab II Pasal 2 ditegaskan bahwa pendidikan nasional berfungsi mengembangkan kemampuan dan membentuk watak serta peradaban bangsa yang bermartabat dalam mencerdaskan kehidupan bangsa, Hal ini bertujuan untuk berkembangnya potensi peserta didik agar menjadi manusia yang beriman dan bertaqwa kepada Tuhan Yang Maha Esa, berakhlak Mulia, sehat, berilmu, cakap, kreatif, mandiri dan menjadi warga Negara yang demokratis serta bertanggung jawab.

Berdasarkan masalah tersebut, perlu dilakukan inovasi pembelajaran yang meliputi media pembelajaran. Media pembelajaran adalah seluruh alat dan bahan yang dapat dipakai untuk mencapai tujuan pendidikan seperti radio, televisi, buku, 
koran, majalah dan sebagainya. Media adalah berbagai jenis komponen dalam lingkungan siswa yang dapat merangsang untuk belajar. ${ }^{1}$

Dalam proses belajar mengajar, media mempunyai arti yang cukup penting karena dengan adanya media penggunaan media pembelajaran dalam kegiatan tersebut, ketidakjelasan bahan yang disampaikan dapat di bantu dengan media pelajaran sebagai perantara. Kerumitan bahan yang di sampaikan kepada anak didik dapat di sederhanakan dengan bantuan media. Media dapat memiliki apa yang kurang mampu di ucapkan melalui kata-kata atau kalimat tertentu. Bahkan keabstrakan dapat dikonkritkan dengan kehadiran media. Dengan demikian anak didik dapat lebih mudah mencerna bahan dari pada tanpa bantuan media.

Pengintegrasian nilai-nilai imtaq dengan media grafis di duga lebih efektif di gunakan dalam pelajaran IPS khususnya Ekonomi di SLTP karena metode pembelajaran ini di dasarkan pada pandangan belajar yang menyatakan bahwa pengertian yang di miliki siswa merupakan bentuknya sendiri dan bukan hasil bentukan dari guru dan pengetahuan dapat di bentuk oleh siswa jika terjadi interaksi aktif antara siswa dengan objek atau orang. Dan siswa selalu mencoba membentuk pengertian dari interaksi tersebut. Pada SMPN 2 Jerowaru, masih menggunakan pembelajaran yang tergolong membosankan bagi siswa seperti metode ceramah, metode diskusi, serta metode di mana siswa di suruh diam dan mencatat serta mengharap apa yang di sampaikan oleh guru. Kemampuan belajar IPS Terpadu siswa yang ketuntasannya masih dengan nilai rata-rata 4,5. Sementara nilai ketuntasan belajar siswa yang di tetapkan oleh sekolah minimal mendapatkan nilai 6,0. Hal ini terlihat dari kemampuan belajar siswa pada mata pelajaran IPS Terpadu masih di bawah nilai rata-rata dari kriteria ketuntasan minimal (KKM).

Berkaitan dengan hal tersebut, dalam upaya meningkatkan keimanan dan ketaqwaan siswa melalui lembaga pendidikan sekolah, Direktorat Jenderal Manajemen Pendidikan Dasar dan Menengah mengembangkan lima strategi, yakni optimalisasi pelaksanaan pendidikan agama islam, Integrasi IPTEK dan berwawasan

1 Yamin, Martinis. 2004. Strategi Pembelajaran Berbasis Kompetensi. Jakarta: Gaung Persada Press. Tahun 2004), $3 \& 5$. 
imtaq, penciptaan situasi yang kondusif dalam kehidupan sosial di sekolah, dan melaksanakan kerjasama antara orangtua dan masyarakat.

Dan juga lembaga pendidikan dapat membentuk karakter yang kuat untuk dapat menanggulangi dekadensi moral dalam kehidupan sehari-hari baik di lingkungan sekolah maupun keluarga dan masyarakat. ${ }^{2}$

Berdasarkan uraian di atas, maka peneliti bermaksud mengadakan penelitian tentang "Pengintegrasian Nilai-Nilai Imtaq Dengan Media Grafis Dalam Belajar IPS Terpadu Terhadap Hasil Belajar Siswa Kelas VIII Di SMPN 2 Jerowaru"

\section{KAJIAN TEORI}

\section{Pengertian Belajar}

Belajar adalah suatu proses usaha yang dilakukan individu untuk memperoleh suatu perubahan tingkah laku yang baru secara keseluruhan, sebagai hasil pengalaman individu itu sendiri dalam interaksinya dengan lingkungan. ${ }^{3}$

Dari teori diatas, maka dapat disimpulkan bahwa belajar adalah suatu proses perubahan di dalam kepribadian dan tingkah laku manusia dalam bentuk kebiasaan, penguasaan pengetahuan atau keterampilan dan sikap berdasarkan latihan dengan pengalaman dalam mencari informasi, memecahkan masalah, mencermati lingkungan untuk mengumpulkan pengetahuan-pengetahuan melalui pemahaman, penguasaan, ingatan dan pengungkapan kembali di waktu yang akan datang. Belajar berlangsung terus menerus dan tidak boleh dipaksakan tetapi biarkan belajar bebas dalam mengambil keputusan dan bertanggung jawab atas keputusan yang diambilnya.

Untuk mengetahui berhasil atau tidaknya usaha siswa dan guru dalam proses belajar mengajar perlu diadakan evaluasi. Salah satu sasaran yang ingin dicapai dalam kegiatan evaluasi adalah hasil belajar siswa. Tujuan hasil belajar adalah mendorong

${ }^{2}$ Samani, Muchlas, Hariyanto, Pendidikan Karakter. (Bandung: PT Remaja Rosdakarya, Tahun 2011), 72 .

3 Slameto. Belajar Dan Faktor-faktor Yang Mempengarubinya. (Jakarta: Rineka Cipta, Tahun 2003), 2. 
dan mengembangkan kemampuan belajar siswa, kemampuan mengajari siswa, serta menyempurnakan program pengajaran. ${ }^{4}$

Hasil belajar adalah kemampuan yang dicapai anak setelah melalui kegiatan belajar. Belajar ini sendiri merupakan suatu proses dari seseorang yang berusaha untuk memperoleh suatu perubahan tingkah laku yang relatif menetap.

Secara garis besar hasil belajar dibagi menjadi tiga ranah yaitu ranah kongnitif, ranah afektif, dan ranah psikomotorik.

1. Ranah kongnitif berkenaan dengan hasil belajar yang terdiri dari enam aspek, yaitu; pengetahuan atau ingatan, pemahaman, aplikasi, analisis, sintesis, dan evaluasi, kedua aspek pertama disebut kongnitif tingkat rendah dan keempat asfek berikutnya termasuk tingkat tinggi.

2. Ranah afektif berkenaan dengan sikap yang terdiri dari lima aspek, yaitu penerimaan, jawaban atau reaksi, penilaian, organisasi, dan internalisasi.

3. Ranah psikomotorik berkenaan dengan hasil belajar keterampilan dan kemampuan bertindak yang terdiri dari enam aspek, yakni gerakan refleks, keterampilan gerakan dasar, kemampuan perseptual, keharmonisan dan ketetapan gerakan keterampilan kompleks, dan gerakan ekspesif dan interpretatif. $^{5}$

Dari definisi tersebut di atas, tidak ada kontradiksi makna bahkan pengertian satu dengan yang lainnya saling melengkapi, dengan demikian dapat dikatakan bahwa hasil belajar merupakan kemampuan aktual yang dapat diukur dan berwujud penguasaan ilmu pengetahuan, sikap keterampilan, nilai-nilai yang dicapai oleh siswa sebagai hasil dari proses belajarnya di sekolah.

\section{Pengintegrasian Nilai-nilai Imtaq}

Zaman Saleh Hasibuan berpendapat bahwa, "Pengintegrasian pelajaran agama dan pelajaran umum di sekolah-sekolah di indonesia selama ini seolah dua kubu disiplin ilmu yang amat berjauhan, seandainya kedua kubu itu dikaji secara

${ }^{4}$ Ibid, 34 .

${ }^{5}$ Sujana, Nana. Penilaian Hasil Proses Belajar Mengajar, (Bandung: PT. Remaja Rosdakarya, Tahun 2008), 23. 
mendalam pasti akan berdekatan dan saling terkait". ${ }^{6}$ Oleh karena itu, ilmu agama dan ilmu umum pada mulanya satu yaitu sama-sama ilmu Tuhan, timbul dikotomi ilmu agama dan ilmu umum karena luasnya lingkup bahasan ilmu untuk kemudahan memahami dan mempelajarinya. Akibat pemilihan itu muncul lembaga pendidikan yang beraneka ragam mengikuti pemilihan disiplin ilmu. Di dalam sebuah lembaga pendidikan juga terjadi pemilihan antara ilmu agama dan ilmu umum semakin menganga, buku bahan mengikuti pemilihan ilmu agama dan para guru hanya berpegang kepada buku ajar yang ada. Akibat berikutnya muncul selera di kalangan pelajar memilih-milih antara ingin memperdalam ilmu agama dan ilmu umum.

Untuk melakukan pengintegrasian pelajaran agama dan pelajaran umum membutuhkan dua ketentuan :

1. Keterampilan guru agama memperkaya mata pelajaran yang ditanganinya dengan pengetahuan umum, dan keterampilan guru umum memperkaya mata pelajaran yang ditanganinya dengan pengetahuan agama.

2. Untuk membantu peningkatan kemampuan guru dalam memperkaya mata pelajaran masing-masing dibutuhkan kegandaan buku mata ajar yang saling berinteraksi antara pelajaran umum dan pelajaran agama.

Seandainya pihak guru mendapat pendidikan dan latihan secara rutin tentang pengintegrasian kedua ilmu. Upaya pengintegrasian dua materi pelajaran ini perlu dilaksanakan mulai dari SD hingga perguruan tinggi demi peningkatan mutu lulusan.

\section{Media Grafis}

Media adalah perantara atau pengantar pesan dari pengirim pesan ke penerima pesan. Sedangkan dalam bahasa Arab, media adalah perantara atau pengantar pesan dari pengirim pesan kepada penerima pesan. ${ }^{7}$

Dari pendapat tersebut di atas dapat disimpulkan bahwa media adalah segala sesuatu yang dapat dipergunakan untuk menyalurkan pesan dan dapat merangsang

\footnotetext{
${ }^{6} \mathrm{www} / /$ http.sekolahindonesia.com./Integrasi nilai-nilai imtaq. diakses 20 Desember 2010.

${ }^{7}$ Arif, S, Sadiman, dkk. Media Pendidikan, (Jakarta: PT. Raja Grafindo Persada. Tahun 2008), 6.
} 
pikiran, dapat membangkitkan semangat, perhatian, dan kemauan siswa sehingga dapat mendorong terjadinya proses pembelajaran pada diri siswa.

Berdasarkan pengertian diatas, maka media grafis adalah suatu penyajian secara visual yang menggunakan gambar-gambar atau media visual yang lainnya. Beberapa jenis media grafis antara lain:

1. Bagan

Seperti halnya dengan media grafis yang lain, bagan atau chart termasuk media visual, fungsinya yang pokok adalah menyajikan ide-ide atau konsepkonsep yang sulit bila hanya disampaikan secara tertulis atau lisan secara visual.

2. Poster

Poster merupakan media grafis perpaduan antara gambar dengan tulisan untuk menyampaikan kesan-kesan tertentu tapi dia mampu pula untuk mempengaruhi dan memotivasi tingkah laku orang yang melihatnya.

3. Gambar

Gambar karya tangan foto teknik, fotografi, penyajian objek melalui gambar mengungkapkan bentuk nyata maupun kreasi khayalan belaka sesuai bentuk yang pernah dilihat oleh yang menggambarnya.

4. Peta dan Globe

Pada dasarnya peta dan globe berfungsi untuk menyajikan data- data lokasi.

5. Kartun dan Karikatur

Kartun sebagai suatu bentuk komunikasi adalah suatu gambar interpretatif yang menggunakan simbol-simbol untuk menyampaikan suatu pesan secara cepat dan ringkas atau suatu sikap terhadap orang, situasi atau kejadian-kejadian tertentu. Kemampuannya besar sekali untuk menarik perhatian, mempengaruhi sikap maupun tingkah laku.

6. Komik

Komik adalah suatu bentuk sajian cerita dengan gambar seri atau cerita bergambar.

7. Papan Flanel ( Flannel Board)

Papan flanel adalah media grafis yang efektif sekali untuk menyajikan pesan-pesan tertentu kepada sasaran tertentu pula. Papan berlapiskan flanel ini 
dapat dilipat sehingga praktis. Gambar-gambar yang akan disajikan dapat dipasang dan dicopot dengan mudah sehingga dapat dipakai berkali-kali.

8. Papan Buletin ( bulletin board)

Berbeda dengan papan flanel, papan buletin ini dilapisi kain flanel tetapi langsung ditempel gambar-gambar atau tulisan-tulisan. Fungsinya selain menerangkan sesuatu, papan buletin dimaksud untuk memberitahukan kejadian dalam waktu tertentu.

9. Grafik

Sebagai suatu media visual, grafik adalah gambar sederhana yang menggunakan titik-titik, garis atau gambar untuk melengkapinya sering kali simbol-simbol verbal digunakan pula disitu. ${ }^{8}$

\section{Tinjauan tentang Permintaan dan Penawaran serta Terbentuknya Harga Pasar}

Pasar sebagai salah satu sarana kegiatan ekonomi masyarakat melibatkan penjual dan pembeli dalam kegiatannya, pasar merupakan bagian penting dalam kegiatan perekonomian. Di dalam kegiatan pasar, para pembeli berdatangan dari berbagai tempat dengan tujuan mendapatkan barang dan jasa yang dibutuhkannya. Keinginan pembeli untuk memiliki barang dan jasa itu biasa disebut sebagai permintaan. Permintaan terhadap barang dan jasa akan dapat dipenuhi dengan kegiatan.

\section{METODE PENELITIAN}

Adapun jenis penelitian yang digunakan adalah penelitian eksperimen dengan menggunakan metode quasi eksperimen yang melibatkan dua kelompok yaitu kelompok eksperimen dan kelompok kontrol, kelompok kontrol digunakan sebagai standar eksternal. Desain penelitian yang digunakan yaitu dengan menggunakan pre-test post- tes control group design. Eksperimen digunakan menganalisis adalah quasi exsperimental.

${ }^{8}$ Ibid, 29. 
Persyaratan yang di maksud adalah sudah adanya kelompok lain yang tidak di kenai eksperimen yaitu kelompok kontrol. Dengan adanya kelompok lain ini sebagai kelompok pembanding maka akibat yang diperoleh dari perlakuan yang diberikan dapat dilihat secara pasti dibandingkan yang tidak diberikan perlakuan.

Tabel 1 : Gambaran desain penelitiannya sebagai berikut :

\begin{tabular}{|c|c|c|c|}
\hline Kelompok & Pree- test & Perlakuan & Past- test \\
\hline E & Q1 & X & Q2 \\
\hline K & Q3 & - & Q4 \\
\hline
\end{tabular}

Di mana:

E : Kelompok Eksperimen

$\mathrm{K}$ : Kelompok Kontrol

Q1 : Pra Uji / Pre- test Kelompok Eksperimen

Q2 : Pra Uji /Past-test Kelompok Eksperimen

Q3 : Pra Uji / Pree- test Kelompok Kontrol

Q4 : Pasca uji Post-test Kelompok kontrol

$\mathrm{X}:$ Perlakuan $^{9}$

Apabila seseorang peneliti ingin meneliti semua elemen yang ada dalam wilayah penelitian, maka penelitiannya merupakan penelitian populasi. Semua objek atau individu yang memiliki karakteristik tertentu, jelas dan lengkap yang akan diteliti disebut populasi. ${ }^{10}$

Berdasarkan pendapat di atas dapat disimpulkan bahwa subjek penelitian itu juga disebut populasi penelitian, populasi penelitian meliputi seluruh individu yang memiliki objek atau masalah yang sama yang hendak dikaji melalui penelitian. Populasi dalam penelitian ini adalah siswa kelas VIIIa dan VIIIb di SMPN 2 Jerowaru.

Teknik Pengambilan Sampel dengan cara sample random sampling (acak sederhana), yaitu seluruh elemen dalam populasi di perhitungkan dan tiap elemen mempunyai kesempatan yang sama untuk terpilih sebagai subjek yang terdiri dari 22 orang siswa kelas VIIIa dan 22 orang siswa kelas VIIIb.

9 Arikunto Suharsimi. Dasar-dasar Evaluasi Pendidikan, Jakarta: PT. Rineka Cipta. Tahun 2006), 86.

${ }^{10}$ Hasan Iqbal. Pokok-pokok Materi Statistik 1 (Statistik Inferensif) Edisi Dua. (Jakarta: Bumi Aksara, Tahun 2003), 84. 
Teknik yang digunakan dalam pengambilan data adalah tes hasil belajar. Teknik ini digunakan untuk mendapatkan data atau nilai hasil belajar siswa.

Instrumen yang digunakan dalam penelitian ini adalah tes, yaitu tes kemampuan menyelesaikan soal-soal baik yang diajarkan dengan penggunaan metode media grafis maupun konvensional. Tes yang baik harus memenuhi syarat yang penting, yaitu meliputi (a). Uji validitas, (b). Uji Realibilitas, (c). Uji Tingkat Kesukaran, (d). Uji Daya Beda Soal.

Teknik analisis data adalah suatu cara yang digunakan untuk menyusun data yang terkumpul sehingga dapat menghasilkan kesimpulan yang dapat dipertanggung jawabkan kebenarannya. Untuk memberikan gambaran yang jelas tentang dan masing-masing variabel, serta untuk menguji hipotesis penelitian maka terlebih dahulu dilakukan analisis data. Data yang diperoleh dideskripsikan dengan menggunakan statistik deskriptif. Statistik deskriptif ini meliputi penentuan skor ratarata atau mean dan standar deviasi. Teknik uji persyaratan analisis data menggunakan uji normalitas data dan uji homogenitas data.

Uji hipotesis ini digunakan untuk mengetahui tingkat signifikan dari pengaruh variabel independen terhadap variabel dependen secara individual dan menganggap dependen yang lain konstan. Signifikansi pengaruh tersebut dapat diestimasi dengan membandingkan antara nilai t tabel dengan nilai t hitung. Apabila nilai t hitung lebih besar dari nilai t tabel maka variabel independen secara individual mempengaruhi variabel dependen, sebaliknya jika nilai t hitung lebih kecil daripada t tabel maka variabel independen secara individual tidak mempengaruhi variabel dependen.

$$
t_{\text {hitung }}=\frac{\overline{X_{1}}-\overline{X_{2}}}{\sqrt{\frac{\left(n_{1}-1\right) s_{1}^{2}+\left(n_{2}-1\right) s_{2}^{2}}{n_{1}+n_{2}-2}\left[\frac{1}{n_{1}}+\frac{1}{n_{2}}\right]}}
$$

Keterangan :

$\mathrm{n}_{1}=$ Jumlah sampel pertama

$\mathrm{n}_{2}=$ Jumlah sampel kedua

$\overline{\mathrm{X}}_{1}=$ Angka rata-rata dari sampel $\mathrm{X}_{1}$, dicari dengan rumus $\frac{\sum \mathrm{x}_{1}}{\mathrm{n}_{1}}$

$\overline{\mathrm{X}}_{2}=$ Angka rata-rata dari sampel $\mathrm{X}_{2}$, dicari dengan rumus $\frac{\sum \mathrm{x}_{\mathrm{z}}}{\mathrm{n}_{\mathrm{z}}} 11$

11 Ibid, 155. 


\section{HASIL PENELITIAN}

Penelitian ini menggunakan penelitian eksperimen dengan menggunakan metode quasi eksperimen yang melibatkan kelompok eksperimen dan kelompok kontrol, kelompok kontrol digunakan sebagai standar eksternal. Desain penelitian yang digunakan yaitu dengan menggunakan pre-tes pos-tes control group design. Eksperimen yang digunakan menganalisis adalah quasi experimental. Adapun rincian data hasil penelitian ini di uraikan sebagai berikut:

\section{Data hasil belajar siswa kelompok eksperimen untuk pre-test}

Berdasarkan hasil pengumpulan data (Lampiran 04) di peroleh skor terendah bagi kelompok eksperimen untuk pree test adalah 40 dan skor tertinggi 75. Dari perhitungan data tersebut nilai rata-rata 55,05 dan Standar Deviasi 11,42 (Lampiran 05) Selanjutnya untuk keperluan pengkategorian perlu dicari Mi dan SDi dari data hasil belajar siswa kelompok eksperimen untuk pree test dan SDi, karena skor maksimal ideal $=100$ dan skor minimal ideal $=0$, maka diperoleh Mi dan SDi adalah $\mathrm{Mi}=1 / 2(100+0)=50$ dan SDi $=\frac{1}{6}(100-0)=16,67$.

Berdasarkan perolehan Mi dan SDi diatas, maka dapat dibuat nilai konversi pengkategorian hasil belajar siswa kelompok eksperimen untuk pree- test adalah sebagai berikut:

$$
\begin{aligned}
& \text { Mi }=1 / 2 \mathrm{x}(\text { skor maksimal }+ \text { skor minimal ideal }) \\
& 1 / 2 \times(100+0)=50 \\
& \mathrm{SDi}=\frac{1}{6} \times(100-0)=16,67 \\
& \mathrm{Mi}+1 \text { SDi sampai < Mi + } 3 \text { SDi kategori tinggi } \\
& 50+1(16,67) \text { sampai }<50+3(16,67) \\
& \text { 66,67 sampai }<100 \\
& \mathrm{Mi} \text { - SDi sampai < Mi + } 1 \text { SDi kategori sedang } \\
& 50-16,67 \text { sampai }<50+1(16,67) \\
& \text { 33,33 sampai }<66,67 \\
& \text { Mi }-3 \text { SDi sampai }<\text { Mi - } 1 \text { SDi kategori rendah } \\
& 50-3(16,67) \text { sampai }<50-1(16,67) \\
& 0 \text { sampai }<33,33
\end{aligned}
$$


Berdasarkan pengkategorian diatas, mean yang diperoleh yaitu 55,05, maka secara umum dapat digolongkan bahwa hasil belajar siswa kelompok ekperimen untuk pree test tergolong sedang.

\section{Data hasil belajar siswa kelompok eksperimen untuk post- test}

Berdasarkan hasil pengumpulan data ( Lampiran 04 ) diperoleh skor terendah bagi siswa kelompok eksperimen untuk post tes dengan pengintegrasian nilainilai imtaq dengan media grafis adalah skor terendah 40 dan skor tertinggi 80 . Dari perhitungan data tersebut nilai rata-rata 58,86 dan Standar Deviasi 10,91.

Selanjutnya berdasarkan hasil belajar siswa kelompok eksperimen untuk post tes diperoleh Mi dan SDi sebagai keperluan pengkategorian, karena skor maksimal ideal $=100$ dan skor minimal ideal $=0$, maka diperoleh Mi dan SDi adalah $\mathrm{Mi}=1 / 2(100+0)=50$ dan SDi $=\frac{1}{6}(100-0)=16,67$.

Berdasarkan perolehan Mi dan SDi diatas, maka dapat dibuat nilai konversi pengkategorian hasil belajar siswa kelompok eksperimen untuk pos tes adalah sebagai berikut:

$$
\begin{aligned}
& \text { Mi + } 1 \text { SDi sampai Mi + } 3 \text { SDi Kategori Tinggi } \\
& 50+1(16,67) \text { sampai } 50+3(16,67) \\
& \text { 66,67 sampai } 100 \\
& \text { Mi - SDi sampai < Mi + } 1 \text { SDi Kategori Sedang } \\
& 50-(16,67) \text { sampai }<50+1(16,67) \\
& \text { 33,33 sampai }<66,67 \\
& \text { Mi - } 3 \text { SDi sampai < Mi - } 1 \text { SDi Kategori Rendah } \\
& 50-3(16,67) \text { sampai }<50-1(16,67) \\
& 0 \text { sampai }<33,33
\end{aligned}
$$

Berdasarkan pengkategorian diatas, mean yang diperoleh yaitu 58,68, maka secara umum dapat digolongkan bahwa hasil belajar siswa kelompok eksperimen untuk post tes tergolong sedang. 


\section{Hasil uji normalitas}

Uji normalitas tes hasil belajar antara kelompok eksperimen dengan kelompok kontrol bertujuan untuk mengetahui apakah antar kelompok sampel tersebut berasal dari populasi yang berdistribusi normal atau tidak. Data yang digunakan untuk uji normalitas diambil dari tes akhir masing- masing kelompok, dari data tersebut didapatkan hasil yang secara ringkas dapat dilihat pada tabel dibawah ini

Tabel 2 : Uji Normalitas Data Tes Akhir

\begin{tabular}{|l|l|l|l|}
\hline Eksperimen & $\mathrm{X}^{2}{ }_{\text {hitung }}$ & $\mathrm{x}_{\text {tabel }}$ & Kriteria \\
\hline Pre-Tes & 7,00 & 7,81 & Terdistribusi Normal \\
Post-Tes & 4,25 & 7,81 & Terdistribusi Normal \\
\hline
\end{tabular}

Sumber : Hasil pengolahan data primer

Dari tabel diatas diketahui $\mathrm{X}_{\text {hitung }}^{2}$ kelompok eksperimen untuk Pre-test adalah 4,25 dan $\mathrm{X}_{\text {tabel }}^{2} 7,81$ maka dapat dikatakan kelompok eksperimen untuk Pre-test berasal dari populasi yang terdistribusi normal karena $\mathrm{X}_{\text {tabel }}^{2}>\mathrm{X}_{\text {hitung }}^{2}$ yaitu 7,81>4,25. Sedangkan $\mathrm{X}_{\text {hitung }}^{2}$ kelompok eksperimen untuk Post-test adalah 7,00 dan $\mathrm{X}_{\text {tabel }}^{2} 7,81$ maka dapat dikatakan kelompok eksperimen untuk post-test berasal dari populasi yang terdistribusi normal karena $X_{\text {tabel }}^{2}>X_{\text {hitung }}^{2}$ yaitu 7,81>7,00. Sehingga dapat disimpulkan bahwa kedua kelompok tersebut berasal dari populasi yang sama.

\section{Hasil uji homogenitas}

Uji homogenitas bertujuan untuk mengetahui apakah kelompok eksperimen maupun kelompok kontrol berasal dari sampel yang sama (Homogen). Data yang digunakan untuk menentukan homogen atau tidaknya kedua kelompok diambil dari hasil tes akhir untuk masing-masing kelompok. Berdasarkan hasil perhitungan diperoleh $\mathrm{X}_{\text {hitung }}=2,30$ dan $\mathrm{X}_{\text {tabel }}=7,81$. Berdasarkan kriteria yang ada yaitu apabila $\mathrm{X}_{\text {hitung }}<\mathrm{X}_{\text {tabel }}$ maka kedua kelompok tersebut berasal dari sampel yang homogen, artinya kedua kelompok mempunyai kemampuan awal yang sama. Hal tersebut juga terlihat dari hasil pembelajaran selama proses belajar mengajar berlangsung, kedua kelas sama-sama merespon pembelajaran dengan baik. 


\section{Hasil pengujian hipotesis}

Setelah diketahui bahwa kedua kelompok tersebut berasal dari populasi yang berbeda, maka dapat dilakukan uji pengaruh media grafis terhadap hasil belajar IPS Terpadu pada siswa dengan menggunakan uji t. Uji-t yang digunakan dalam penelitian ini adalah uji t. Data yang digunakan untuk pengujian adalah data tes akhir hasil belajar, dari data tersebut diperoleh hasil perhitungan skor rata-rata kelompok eksperimen untuk post-test adalah 58,86 dengan jumlah siswa 22 orang siswa dan skor rata-rata kelompok eksperimen untuk pre-test adalah 55,05 dengan jumlah siswa 22 orang siswa, sehingga dapat dikatakan $\mathrm{X}_{1} \geq \mathrm{X}_{2}$ karena pada kelompok eksperimen untuk post-test jumlah siswa yang mendapatkan nilai tinggi lebih banyak daripada siswa kelompok ekperimen untuk pree-test. Dari data-data diatas didapatkan t-tes adalah 1,925 sedangkan dari tabel distribusi t-tes dengan taraf signifikan 5\% diperoleh $\mathrm{t}$ tabel adalah 1,684. Dengan hasil tersebut yaitu $\mathrm{t}_{\text {tes }}>\mathrm{t}_{\text {tabel }}$ maka bisa dikatakan hipotesis Ho ditolak dan Ha diterima, ini menunjukkan bahwa ada perbedaan penggunaan media grafis dengan pengintegrasian nilai-nilai imtaq terhadap peningkatan hasil belajar siswa dari pada kelompok yang diajarkan dengan media grafis tanpa pengintegrasian nilai-nilai imtaq.

\section{PEMBAHASAN}

Berdasarkan hasil analisis menunjukkan bahwa prestasi belajar IPS Terpadu siswa yang diajarkan dengan media grafis dengan pengintegrasian nilai-nilai imtaq ada perbedaan hasil belajar IPS Terpadu siswa yang diajarkan dengan media grafis tanpa pengintegrasian nilai-nilai imtaq. Hal ini dapat dilihat dari hasil belajar siswa sesudah dilakukan perlakuan pada masing- masing kelompok. Setelah diberikan kegiatan pembelajaran dan dari tes akhir (post-test) diperoleh skor rata-rata kelompok eksperimen untuk post test adalah 58,86 sedangkan skor rata-rata kelompok eksperimen untuk pre-test adalah 55,05. Dari hasil rata-rata nilai tes akhir tersebut antara kedua kelompok yaitu kelompok eksperimen untuk post-test dan kelompok ekperimen untuk pre-test, dapat dikatakan bahwa rata-rata hasil belajar kelompok eksperimen untuk post test lebih baik dari rata-rata kelompok eksperimen pre-test.

Setelah melakukan uji statistik dengan menggunakan t-tes didapatkan bahwa hasil tes akhir dari kelompok eksperimen untuk post-tes yang diajarkan dengan 
menggunakan media grafis dengan pengintegrasian nilai-nilai imtaq lebih baik jika dibandingkan dengan hasil belajar siswa pada kelompok eksperimen untuk pre-tes yang diajarkan dengan media grafis tanpa pengintegrasian nilai-nilai imtaq, pada taraf signifikan 5\% dengan harga t-tes yaitu 1,925 nilai ini lebih besar dari t-tabel yaitu 1,684, dan dengan kata lain hipotesis Ha diterima. Dari hasil pengujian tersebut terlihat bahwa menggunakan media grafis dengan pengintegrasian nilai-nilai imtaq dalam pembelajaran IPS Terpadu berpengaruh positif terhadap hasil belajar siswa.

Perbedaan hasil belajar ini telah terlihat dari perilaku siswa pada saat proses belajar mengajar berlangsung, dimana kelas eksperimen untuk post-tes lebih bersemangat untuk belajar dibandingkan kelas eksperimen untuk pre-test. Ini disebabkan karena pada kelas eksperimen untuk post-test pembelajaran dilakukan lebih menarik dengan menggunakan media-media sehingga siswa lebih bersemangat dan termotivasi untuk belajar.

Melihat hasil belajar yang dicapai oleh siswa dengan menggunakan media grafis, maka media grafis merupakan salah satu alternatif pilihan dalam proses belajar mengajar untuk meningkatkan hasil belajar siswa, karena bukan hanya hasil tinggi, tetapi juga bisa menumbuhkan rasa imajinasi dalam memvisualisasikan materi-materi lainnya dalam pembelajaran.

\section{KESIMPULAN}

Berdasarkan hasil penelitian yang telah dilakukan, maka dapat ditarik kesimpulan bahwa penggunaan pengintegrasian nilai-nilai imtaq dengan media grafis lebih efektif untuk meningkatkan hasil belajar siswa bila dibandingkan dengan yang tidak menggunakan pengintegrasian nilai-nilai imtaq tanpa media grafis pada siswa kelas VIII SMPN 2 Jerowaru. Hal ini terlihat dari nilai rata-rata pada setiap kelompok. Dari hasil analisis data, diperoleh nilai rata-rata kelompok yang menggunakan pengintegrasian nilai-nilai imtaq dengan media grafis 58,86 dan kelompok yang tidak menggunakan pengintegrasian nilai-nilai imtaq tanpa media grafis 55,05. Sedangkan dari hasil uji hipotesis diperoleh t-hitung lebih besar dari ttabel yaitu 1,925 > 1,684. Hal ini berarti bahwa hipotesis yang diajukan diterima (Ho ditolak dan Ha diterima). 


\section{SARAN}

Bagi Kepala sekolah, diharapkan dapat memiliki kepedulian tentang penggunaan metode yang disediakan oleh lapangan dalam pembelajaran pada pokok bahasan yang diajarkan. Kesadaran kepedulian ini sangat menentukan aktivitas dalam proses belajar mengajar, apalagi guru yang selalu sadar ingin belajar menambah ilmu pengetahuan untuk kepentingan profesinya. Kepada guru kelas, hendaknya selalu membantu siswa untuk mengatasi kesulitan yang dihadapi terhadap penguasaan materi- materi pembelajaran khususnya pada mata pelajaran Ilmu Pengetahuan Sosial. Kepada Siswa disarankan agar lebih banyak belajar dengan mengulangi pelajaran yang telah diberikan, khususnya pada mata pelajaran IPS. Kepada sekolah meliputi kepala sekolah agar memberikan perhatian dan motivasi terhadap guru-guru khususnya agar selalu memberikan pengarahan untuk menggunakan metode pembelajaran yang bervariasi dalam proses belajar mengajar di sekolah. Kepada Orang Tua diharapkan kepada semua orang tua siswa agar benar-benar memperhatikan keberadaan anaknya dirumah. Ikut membantu dan mendorong untuk belajar sehingga para siswa dapat mencapai proses belajar yang memuaskan.

\section{DAFTAR PUSTAKA}

Arif, S, Sadiman, dkk. (2008). Media Pendidikan. Jakarta: PT. Raja Grafindo Persada.

Arikunto Suharsimi, (2006). Dasar-dasar Evaluasi Pendidikan. Jakarta: PT. Rineka Cipta. Arikunto Suharsimi, (2001). Prosedur Penelitian Suatu Pendekatan Praktik. (Edisi Revisi IV). Jakarta: PT. Rineka Cipta.

Hasan Iqbal, (2002). Pokok-pokok Materi Statistik 1 (Statistik Deskriptif) Edisi Dua. Jakarta: Bumi Aksara.

Hasan Iqbal, (2003). Pokok-pokok Materi Statistik 1 (Statistik Inferensif) Edisi Dua. Jakarta: Bumi Aksara.

Maman Abdurrahman, (2007). Analisis Korelasi, Regresi, Dan Jalur Dalam Penelitian. Bandung: CV. Pustaka Setia.

Slameto. (2003). Belajar Dan Faktor-faktor Yang Mempengarubinya. Jakarta: Rineka Cipta.

Samani, Muchlas, Hariyanto, (2011) Pendidikan Karakter, Bandung: PT. Remaja Rosdakarya. 
Muhamad Zaril Gapari

Sujana, Nana. (2008). Penilaian Hasil Proses Belajar Mengajar. Bandung: PT. Remaja Rosdakarya.

Yamin, Martinis, (2004). Strategi Pembelajaran Berbasis Kompetensi. Jakarta: Gaung Persada Press.

www//http.sekolahindonesia.com./Integrasi nilai-nilai imtaq. diakses 20 Desember 2010. 